\title{
The Role of School Principals in the Governorate of Ma'an in Promoting Intellectual Security among Students
}

\author{
Dima Waswas ${ }^{1} \&$ Al-Mothana M. Gasaymeh ${ }^{1}$ \\ ${ }^{1}$ Curriculum \& Instruction Department, Al-Hussein Bin Talal University, Ma'an, Jordan \\ Correspondence: Dima Waswas, Curriculum \& Instruction Department, Al-Hussein Bin Talal University, Ma'an, \\ Jordan. E-mail: dmwaswas@yahoo.com
}

Received: September 14, 2016

Accepted: October 25, $2016 \quad$ Online Published: November 23, 2016

doi:10.5539/jel.v6n1p193

URL: http://dx.doi.org/10.5539/jel.v6n1p193

\begin{abstract}
This study aims at identifying the role played by school principals in the Governorate of Ma'an to strengthen intellectual security of the school students; and identifying whether there are statistically significant differences in the roles of principals attributed to the variables: gender, academic level, and years of experience in administration.

To achieve this, the researchers adopted the descriptive approach which is appropriate for the nature of this study. Data were collected and analyzed by using a questionnaire that determines the role of school principals in the promotion of intellectual security. The questionnaire includes three areas: the role of principals toward teachers, the role of principals toward school activities, and the role of principals toward community service. The study sample consisted of 120 male and female school principals in Ma'an governorate.

The results showed that the arithmetic means of the three domains in the questionnaire ranged from (3.547-4.129) with high degree of agreement; where the domain: "the role of principals toward teachers" scored the highest value, and the domain: "the role of principals toward community service" scored the lowest value.
\end{abstract}

Keywords: intellectual security, school principals, the Governorate of Ma'an

\section{Introduction}

Schools are of one the most important social institutions entrusted with the upbringing of generations, assessing their behavior, and modifying their ideas and attitudes. When crises and tribulations befall nations and communities, schools bear the burden and remain the successful tool to correct concepts. Hence, the roles of the schools in promoting intellectual security and addressing intellectual deviations faced by students became an urgent need and a vital requirement under the current circumstances and the successive challenges in the era of globalization and the transformation of the world into a small village (Al-Sulaiman, 2006).

Security is a goal sought by all communities. Moreover, security awareness is a preventive tool that enables communities to avoid the social and economic consequences of moral deviation. Thus, well-thought-out plans that ensure security awareness should be made. One of the most important fields to achieve this is educational institutions, as these institutions instill security awareness in their fields of study (Al-Hoshan, 2005).

Security includes everything related to the bank of human memory; such as the cultures, values and moral principles that the human receives. It also includes the protection of all his rights related to freedom of choice and freedom of acting provided that this freedom does not violate or conflict with the rights of others; as well as the human's right in maintaining intellectual property (Tomlinson, 2006).

Intellectual security in our contemporary life is no longer just a cultural and intellectual goal; it also became an inclusive target which involves political and national aspects not less important than the intellectual aspects. It is an indispensable element of social advancement, and a manifestation of the ability to be free from external influences. Moreover, intellectual security represents maintaining national identity which was targeted by third parties as a first step absorption and control processes. Those who believe that intellectual security is closing doors and staying away from modern means of communication and media are completely mistaken. Intellectual security is not a negative issue that embodied in keeping people away from potential risks (Mahfouz, 2006). 
Achieving intellectual security for the individual means an automatic achievement of security in all other aspects; as the mind is the focus of the conscious senior leadership in humans. It is entrusted with all other security aspects (Afifi, 2004).

There is no doubt that the concept of intellectual security is relatively new, but its content is as old as human society. Therefore, many contemporary researchers who are interested in the security issue tried to find definitions in this field; Al-Jawarneh (2011) defined security as: keeping the human mind and thought safe from deviance when comprehending religious and political matters.

Al-Luwaihiq (2005) defined security as: the safety of human thought from deviance or getting away from moderation in his understanding of religious, political and social matters; thus, leading to maintaining public order, and achieving tranquility and stability in the political, social and economic life.

While Al-Haider (2002) defined it as: securing the thoughts and minds of community members from any impurities or wrong beliefs which could pose a danger to the security of the society, in order to achieve security and stability in social life.

Since education has an important role in protecting communities from deviant behaviors and thoughts as well as its role in establishing the spiritual and moral values; security can be achieved in communities through making the most of the means of education (Karah, 1999).

There are a number of measures that can be taken by the educational institutions for the contribution in achieving security, namely:

- Continuing the process of students' socialization in order to refine their personality, and to ensure their familiarity with the surroundings.

- Making the student familiar with his social duties; as education is not only an informative but also a social and humanitarian process.

- Expanding the circle of human relations and interacting with various community groups.

- Linking students to the culture prevailing in the community and introducing them to the heritage of their nation, as well as spreading the spirit of innovation and creativity in response to cultural developments and changes.

- The integration of educational efforts between home, school, and community.

- Examining social behavior and lifestyles and introducing them to students to become useful members in the society and to ensure they do not fall in the circle of deviance.

- Training students on discipline and good disposition; the ability to understand the surrounding circumstances, and how to deal with it properly.

- Linking educational activities with the community efforts (Faraj, 2004).

The importance of school management in achieving intellectual security stems from for two facts: first, the school includes all segments of society of all ages. Second, those who run these institutions are the intellects of the nation, and they must meet good qualities (Al-Qarni, 2004).

\section{Previous Studies}

The following is a presentation of previous studies related to intellectual security in the educational institutions. The studies were displayed in chronological order from oldest to newest.

The study of Al-Yousuf (2001) examined the security role of the school in Saudi society. The study aimed at reviewing the impact of education on the general level of criminality, and determining the security themes emphasized by the vocabulary of learning. The study found that the school plays an important security role through its activities and programs in supporting all various security aspects. It also showed the importance of deepening dialogue and openness between educational and security institutions.

Al-Bura'i (2002) aimed to identify the role of university in confronting the issues of intellectual extremism and violence among young people. He used the social survey method through a sample that represented the study population which consisted of three universities. The study found that young people represent the pillar of the future, and they feel worried and frustrated when the state is unable to ensure their unity with social life.

Johnson (2005) aimed at identifying the intellectual security features provided by the Internet to the students in Mankato city in the state of Minnesota, United States. He found that $81 \%$ of the students achieved their intellectual security features in terms of freedom of expression via the Internet. Students also achieved 
intellectual security in terms of freedom of using the internet in education and searching for information that provide them huge amounts of information, thus leading to achieve a kind of intellectual and information security. The researcher also noted that $19 \%$ of the students do not care about knowledge and science provided by the internet; rather, they turn to intellectual and moral deviance in their use of the Internet.

Tomlinson (2006) study pointed out the interest of the educational institutions in strengthening intellectual security principles by integrating ethical and cultural values in the educational curriculum in America. The researcher used the analytical approach through addressing a number of studies that tackled intellectual security issue. The study concluded that the school and the teacher lead a major role in strengthening the intellectual security among students through their efforts in spreading the concepts of values and ethics and culture, which are of the educational foundations upon which the curriculum is based.

Al-Sulaiman (2006) examined the role of school administrations in promoting intellectual security among students. He aimed to determine the role of school administration and its contribution to the promotion of intellectual security among general education students in Riyadh. The researcher used the descriptive approach. He found out that most of the respondents believe that there is a great need to strengthen intellectual security among students. He also found out that $49 \%$ of respondents follow the procedures used in the promotion of intellectual security.

Khoraif (2006) addressed the role of the assistant school principals in achieving intellectual security among the students. He aimed at identifying the means and procedures taken by the school administration for achieving intellectual security. The study showed that there is a great importance of attending seminars and workshops in order to promote the intellectual security of the students; and that there is a great importance of the extracurricular activities programs in the promotion of intellectual security.

Al-Reb'i (2009) examined the role of the curriculum in strengthening the intellectual security concepts among university students in the Kingdom of Saudi Arabia. The study aimed to show the importance of the educational institutions in general and the curriculum in particular, in the formation of the human personality. The study also determined the roles of the school curriculums in explaining, straightening and strengthening the intellectual security concepts among students. The results showed that the role of the curriculum in enhancing intellectual security was moderate; and that the courses that provide the most concepts and information related to intellectual security are those in Education of Islamic Culture.

\section{The Study Problem and Questions}

School is considered one of the most important thought providers of any individual in society. It includes the most important group in society, that is, students of various stages of age. Therefore, students thought can be protected through the provision of sound educational and instructional foundations within the educational processes and within the students' activities.

School administration assumes responsibility to run the educational process, which involves the protection of students from falling into intellectual deviance. School is responsible for protecting students from the effects of ideological invasion. This can be achieved through applying administrative regulations and through providing students with standards and values and moral ideals. Tash (1993) indicates that the school can rectify any defect in the students' behavior through the teachers' instructions; monitoring the pupils' behaviors and actions, as well as any physical, mental or psychological changes; and finding the appropriate remedy for each case.

This study seeks to answer the following questions:

- What is the role of school principals in Ma'an in promoting intellectual security of the students?

- Are there any statistically significant differences attributed to the variables: gender, academic level, and years of experience in administration in the responses of school principals regarding their role in strengthening the intellectual security of the students in the Governorate of Ma'an?

\section{The Importance of the Study}

The importance of this study is determined by the following:

- The importance of intellectual security and its role in promoting national security.

- The important role of school principals in promoting intellectual security.

- The age group for school students is considered the most appropriate period to consolidate the concepts and trends.

- This study provides a set of recommendations for strengthening the role of school principals in the promotion of intellectual security. 


\section{Limitation of the Study}

- This study was limited to identifying the role played by school principals to promote the intellectual security of students.

- This study was conducted during the second semester of the academic year 2015/2016.

- This study was limited to the schools in Ma'an Governorate.

\section{The Study Terms}

The procedural definitions for the main terms of the study:

- School principals' role: a group of procedures emanating from the duties and tasks that are entrusted to the school administrations, derived from the laws and regulations of the Ministry of Education in the Hashemite Kingdom of Jordan.

- Intellectual security: securing school students from deviant thoughts and erroneous beliefs, in order to achieve stability in the various spheres of life.

\section{Methodology and Procedures}

\subsection{The Study Method}

The descriptive approach was appropriate for the nature of this study. A questionnaire based on the theoretical literature and the previous studies was prepared. The questionnaire was distributed to the study sample; then, the data was analyzed using the SPSS statistics.

\subsection{The Study Population and Sample}

The study population included all school principals in the Governorate of Ma'an, totaling 193 principals, according to the directorates of education statistics in the Governorate of Ma'an, in 2016. All the principles were invited to participate in the study. One hundred and twenty principals, in the Governorate of Ma'an, participated in the study. Table 1 shows the distribution of the sample according to the preliminary data. The paper version of the questionnaires were handed to and collected from the principles by group of teachers who worked with the researchers.

Table 1. Distribution of the study sample according to the preliminary data

\begin{tabular}{llll}
\hline Variable & Level & Number & Percentage \\
\hline Gender & Male & 59 & 49.2 \\
& Female & 61 & 50.8 \\
Academic level & Diploma & 10 & 8.3 \\
& Bachelor degree (BA) & 96 & 80.0 \\
& Master degree (MA) & 13 & 10.8 \\
& Doctorate degree (PhD) & 1 & 0.8 \\
Years of experience in administration & Less than 5 years & 22 & 18.3 \\
& From 5-10 years & 72 & 60.0 \\
& More than 10 years & 26 & 21.7 \\
& Sub total & 120 & 100.0 \\
\hline
\end{tabular}

Table 1 shows that:

1) The number of males in the study sample was 59 with a percentage of $49.2 \%$, while the number of females was 61 with a percentage of $50.8 \%$.

2) The academic level (BA) got the highest percentage $80.0 \%$, while the academic level $(\mathrm{PhD})$ got the lowest percentage $0.8 \%$.

3) Years of experience in administration (5-10 years) got the highest percentage $60.0 \%$, while the years of experience in administration at the lowest percentage (less than 5 years) got the lowest percentage $18.3 \%$. 


\subsection{The Study Tool}

The researchers used a questionnaire designed to determine the role of school principals in the Governorate of Ma'an in promoting intellectual security of the students. The questionnaire consisted of three domains: first, the role of principals toward the teachers which included 14 items; second, the role of principals toward school activities and included 9 items; and third, the role of principals toward serving the local community which included 6 items. Total items in the questionnaire were 29 items. Appendix A shows the instrument.

\subsubsection{Validity of the Study Tool}

To determine the validity of the study tool, it was presented to 10 specialized, expert evaluators from the faculty members in a College of Education. In light of the observations and recommendations of the evaluators, some linguistic amendments were made to some of the questionnaire items.

\subsubsection{Reliability of the Study Tool}

To ensure the reliability of the study tool, the Cronbach's Alpha equation was used on the study sample, to determine the stability of the internal consistency of each domain and the instrument as a whole. Table 2 illustrates these values.

Table 2. The reliability coefficient of the domains of the study tool

\begin{tabular}{ll}
\hline Domain & Cronbach's Alpha Value \\
\hline The role of principals toward the teachers & 0.83 \\
the role of principals toward school activities & 0.817 \\
The role of principals toward serving the local community & 0.89 \\
The tool as a whole & 0.71 \\
\hline
\end{tabular}

It can be noticed from Table 2 that the reliability coefficients values for the domains of the study tool and for the tool as a whole ranged between 0.71-0.89 which are high and medium values and sufficient for the purposes of the study.

\subsubsection{Scoring the Questionnaire}

A Likert-type scale was used as follows: very high, high, medium, low, very low, and the following numerical values $(5,4,3,2,1)$ were given respectively. The following statistical was used for the distribution of the arithmetic means:

First: $\quad(1.00-2.49)$ low level

Second: $\quad(2.50-3.49)$ medium level

Third: $\quad(3.50-5.00)$ high level

\section{Statistical Procedures}

In the current study the dependent variable was: the role of school principals in the Governorate of Ma'an in promoting intellectual security. The independent variables:

- Gender: which has two levels, (male and female)

- Academic Level: which has four levels, (Diploma, BA, MA, and PhD)

- Years of experience in administration which has three levels, (less than 5 years, 5-10 years, and more than 10 years)

The researchers used the following statistical procedures: arithmetic means, standard deviations, and Multivariate Analysis of Variance (MANOVA).

\section{Results and Discussion}

This study aims to determine the role of school principals in the Governorate of Ma'an in promoting intellectual security of the students. What follows are the results of this research, according to the study questions. 


\subsection{Answer of the First Question: What Is the Role of School Principals in Ma'an in Promoting Intellectual} Security of the Students?

To answer this question, the arithmetic means and standard deviations for each item of the scale, and for the scale as a whole, were calculated as described in the Tables 3-6.

Table 3. The arithmetic means and standard deviations for each domain of the tool and for the tool as a whole in descending order (according to arithmetic means)

\begin{tabular}{lllll}
\hline No. & Domain & Arithmetic & $\begin{array}{l}\text { Standard } \\
\text { Mean* }\end{array}$ & $\begin{array}{l}\text { Agreement } \\
\text { degree }\end{array}$ \\
\hline 1 & The role of principals toward the teachers & 4.129 & 0.4800 & High \\
2 & The role of principals toward school activities & 3.915 & 0.4580 & High \\
3 & The role of principals toward serving the local community & 3.547 & 0.5590 & High \\
& Domains as a whole & 3.942 & 0.3980 & High \\
\hline
\end{tabular}

* The highest value is 5 .

Table 3 shows that the arithmetic means of the domains ranged from 3.547-4.129 with high degree of agreement. The highest mean value was for the domain "the role of principals toward the teachers" with a standard deviation 0.480 . While the lowest mean value was for the domain "the role of principals toward serving the local community" with a standard deviation of 0.559 . The arithmetic mean for the domains as a whole was 3.942 with a standard deviation 0.398 and a high degree of agreement.

This result can be attributed to the fact that intellectual security has become an important issue for all institutions, especially the educational ones. Educational institutions need to confront the tools of intellectual invasion of society represented by various means of communication. These tools have led to an unprecedented openness on the world. The only way to control such tools is by enhancing intellectual security of students through educational institutions.

\subsubsection{The First Domain: The Role of Principals toward Teachers}

Table 4. The arithmetic means and standard deviations for the respondents' estimates regarding the domain: "the role of principals toward teachers" in descending order

\begin{tabular}{|c|c|c|c|c|}
\hline No. & Item & $\begin{array}{l}\text { Arithmetic } \\
\text { Mean* }\end{array}$ & $\begin{array}{l}\text { Standard } \\
\text { Deviation }\end{array}$ & $\begin{array}{l}\text { Agreement } \\
\text { degree }\end{array}$ \\
\hline 3 & $\begin{array}{l}\text { Encouraging teachers to enroll in courses on the art of dialogue and } \\
\text { persuasion }\end{array}$ & 4.308 & .708 & High \\
\hline 1 & $\begin{array}{l}\text { Urging teachers to clarify the negative effects of deviant thought for the } \\
\text { students }\end{array}$ & 4.300 & .795 & High \\
\hline 4 & Following-up the teachers while solving the problems of students & 4.242 & .710 & High \\
\hline 14 & Avoiding any issues that raises bias when dealing with teachers & 4.192 & .843 & High \\
\hline 11 & $\begin{array}{l}\text { Working with teachers to study the causes of students dropping out of } \\
\text { school }\end{array}$ & 4.117 & .769 & High \\
\hline 5 & $\begin{array}{l}\text { Directing teachers to use different methods of motivation for students, } \\
\text { and avoid abuse and insult }\end{array}$ & 4.108 & .742 & High \\
\hline 2 & $\begin{array}{l}\text { Directing teachers to link the topics of study with the current situation } \\
\text { of the community and its intellectual problems }\end{array}$ & 4.100 & .653 & High \\
\hline 13 & $\begin{array}{l}\text { Preparing teachers intellectually to fight extremist ideas among } \\
\text { students }\end{array}$ & 4.100 & .749 & High \\
\hline 9 & $\begin{array}{l}\text { Making teachers aware of the importance of employing the scientific } \\
\text { method in teaching; and the development of different thinking skills of }\end{array}$ & 4.075 & .790 & High \\
\hline
\end{tabular}


the students

\begin{tabular}{|c|c|c|c|c|}
\hline 12 & Assisting teachers in the fight against extremist ideas among students & 4.075 & .747 & High \\
\hline 6 & $\begin{array}{l}\text { Providing suitable conditions for the psychological mentor to address } \\
\text { deviant behaviors among students }\end{array}$ & 4.067 & .730 & High \\
\hline 7 & $\begin{array}{l}\text { Holding regular meetings with teachers to study the intellectual trends } \\
\text { of the students }\end{array}$ & 4.067 & .742 & High \\
\hline 8 & $\begin{array}{l}\text { Directing teachers to teach students different life skills such as } \\
\text { responsibility and dialogue }\end{array}$ & 4.033 & .744 & High \\
\hline 10 & $\begin{array}{l}\text { Directing Islamic Education teachers toward instilling the right } \\
\text { religious values and concepts }\end{array}$ & 4.017 & .648 & High \\
\hline \multicolumn{2}{|c|}{ The domain: "the role of principals toward teachers" } & 4.129 & .480 & High \\
\hline
\end{tabular}

* The highest value is 5 .

Table 4 shows that the arithmetic means of the items of the domain "the role of principals toward teachers" ranged between 4.017-4.308. The highest value 4.308 was for item no. 3: "Encouraging teachers to enroll in courses on the art of dialogue and persuasion" with a standard deviation 0.708 ; followed by the value 4.300 for item no. 1: "Urging teachers to clarify the negative effects of deviant thought for students" with a standard deviation 0.795 . While the lowest value was for item no. 10: "Directing Islamic Education teachers toward instilling the right religious values and concepts" with a standard deviation 0.648 ; all of which with agreement degree.

This result can be attributed to the high awareness and responsibility among principals toward directing teachers to strengthen intellectual security. The teacher is the closest to the students. He can adjust any defect in their thought and conduct through monitoring their behavior and any intellectual changes that may occur; in order to achieve security and stability of the individual and society.

\subsubsection{The Second Domain: The Role of Principals toward School Activities}

Table 5. The arithmetic means and standard deviations for the respondents' estimates regarding the domain: "the role of principals toward school activities" in descending order

\begin{tabular}{|c|c|c|c|c|}
\hline No. & Item & $\begin{array}{l}\text { Arithmetic } \\
\text { Mean* }\end{array}$ & $\begin{array}{l}\text { Standard } \\
\text { Deviation }\end{array}$ & $\begin{array}{l}\text { Agreement } \\
\text { degree }\end{array}$ \\
\hline 8 & Organizing national and religious celebrations & 4.475 & .6980 & High \\
\hline 7 & $\begin{array}{l}\text { Introducing elements of attraction into students' activities in order to } \\
\text { increase demand for them }\end{array}$ & 4.200 & .7950 & High \\
\hline 6 & The participation of students in the preparation of students' activities & 4.083 & .8050 & High \\
\hline 5 & Organizing visits to various security institutions & 4.058 & .8230 & High \\
\hline 9 & $\begin{array}{l}\text { Encouraging the students' interest in the school theater, and the development } \\
\text { of the acting skill as a means of expression }\end{array}$ & 4.000 & .8500 & High \\
\hline 1 & $\begin{array}{l}\text { Organizing exhibitions and celebrations that preserve the culture of the } \\
\text { community }\end{array}$ & 3.825 & .7290 & High \\
\hline 3 & Encouraging students to participate in various school activities & 3.658 & .6800 & High \\
\hline 2 & $\begin{array}{l}\text { Hosting specialists to give lectures calling for the spreading of intellectual } \\
\text { security and the fight against delinquency }\end{array}$ & 3.567 & .8170 & High \\
\hline 4 & $\begin{array}{l}\text { Utilizing the students' leisure time, especially in the holidays, in scientific } \\
\text { and cultural activities }\end{array}$ & 3.367 & .7550 & Medium \\
\hline \multicolumn{2}{|c|}{ The domain: "the role of principals toward school activities" } & 3.915 & .4580 & High \\
\hline
\end{tabular}

* The highest value is 5 . 
Table 5 shows that the arithmetic means of the items of the domain "the role of principals toward school activities" ranged between 3.367-4.475. The highest value 4.475 was for item no. 8: "Organizing national and religious celebrations" with a standard deviation 0.698 ; followed by the value 4.200 for item no. 7: "Introducing elements of attraction into students' activities in order to increase demand for them" with a standard deviation 0.7950. While the lowest value was for item no. 4: "Utilizing the students' leisure time, especially in the holidays, in scientific and cultural activities" with a standard deviation 0.7550 .

This result is attributed to the clear impact of classroom activities in the refinement of the students' characters, trends and tendencies. This result also shows that school principals were very interested in directing teachers to employ classroom activities in the promotion of intellectual security. As classroom activities have a prominent role in identifying students' abilities and tendencies; instilling and developing positive values; utilizing students' free time in activities that are good for them and their society; and identifying students' problems in order to resolve them.

\subsubsection{The Third Domain: The Role of Principals toward Serving the Local Community}

Table 6. The arithmetic means and standard deviations for the respondents' estimates regarding the domain: "the role of principals toward serving local community" in descending order

\begin{tabular}{|c|c|c|c|c|}
\hline No. & Item & $\begin{array}{l}\text { Arithmetic } \\
\text { Mean* }\end{array}$ & $\begin{array}{l}\text { Standard } \\
\text { Deviation }\end{array}$ & $\begin{array}{l}\text { Agreement } \\
\text { degree }\end{array}$ \\
\hline 1 & $\begin{array}{l}\text { Holding regular meetings with parents in an atmosphere of dialogue and } \\
\text { discussion }\end{array}$ & 3.725 & 0.608 & High \\
\hline 3 & $\begin{array}{l}\text { Guiding students to participate in the national, religious and cultural activities } \\
\text { organized by community centers }\end{array}$ & 3.692 & 0.838 & High \\
\hline 2 & $\begin{array}{l}\text { Integrating the role of the school with other social institutions to cooperate in } \\
\text { the promotion of intellectual security }\end{array}$ & 3.658 & 0.794 & High \\
\hline 4 & $\begin{array}{l}\text { Inviting community members to attend various activities and events at the } \\
\text { school }\end{array}$ & 3.558 & 0.797 & High \\
\hline 5 & Seeking to eliminate any aspects of intellectual deviance in society & 3.450 & 0.942 & Medium \\
\hline 6 & $\begin{array}{l}\text { Making various school facilities available for members of the community in } \\
\text { the summer vacations to practice different activities }\end{array}$ & 3.200 & 1.066 & Medium \\
\hline \multicolumn{2}{|c|}{ The domain: "the role of principals toward serving local community" } & 3.547 & 0.559 & High \\
\hline
\end{tabular}

* The highest value is 5 .

Table 6 shows that the arithmetic means of the items of the domain "the role of principals toward serving local community" ranged between 3.200-3.725. The highest value 3.725 was for item no. 1: "Holding regular meetings with parents in an atmosphere of dialogue and discussion" with a standard deviation 0.698 ; followed by the value 3.692 for item no. 3: "Guiding students to participate in the national, religious and cultural activities organized by community centers" with a standard deviation 0.838 . While the lowest value was for item no. 6 : "Making various school facilities available for members of the community in the summer vacations to practice different activities" with a standard deviation 1.066 and a medium degree of agreement.

This result indicates that there is a great appreciation of the leading role of the school in serving the society. It is not possible to separate school which qualifies students to be active elements in the development process from society. Therefore, schools must provide their members with an environment that is consistent with external community; so that the student does not experience any contradictions between his life inside the school and his life outside the school. Hence, there should be an active role for schools in strengthening the intellectual security of the community. 
9.2 The Second Question: Are There Any Statistically Significant Differences Attributed to the Variables: Gender, Academic Level, and Years of Experience in Administration, in the Responses of School Principals regarding Their Role in Strengthening the Intellectual Security of the Students in the Governorate of Ma'an?

To answer this question, the arithmetic means and standard deviations of the study sample estimates regarding the role of principals in strengthening intellectual security were calculated according to the study variables, as shown in Tables 7-8.

Table 7. The arithmetic means and standard deviations of the respondents estimates regarding the study fields according to the "gender" and "academic level" variables

\begin{tabular}{|c|c|c|c|c|c|c|c|c|c|c|}
\hline \multirow{3}{*}{ Domain } & \multicolumn{4}{|l|}{ Gender } & \multicolumn{6}{|c|}{ Academic Level } \\
\hline & \multicolumn{2}{|l|}{ Male } & \multicolumn{2}{|l|}{ Female } & \multicolumn{2}{|c|}{ Diploma } & \multicolumn{2}{|c|}{ Bachelor } & \multicolumn{2}{|l|}{ Master } \\
\hline & Mean & SD & Mean & SD & Mean & SD & Mean & SD & Mean & $\mathrm{SD}$ \\
\hline $\begin{array}{l}\text { The role of } \\
\text { principals } \\
\text { toward the } \\
\text { teachers }\end{array}$ & 4.128 & 0.542 & 4.129 & 0.416 & 4.129 & 0.348 & 4.098 & 0.505 & 4.341 & 0.346 \\
\hline $\begin{array}{l}\text { The role of } \\
\text { principals } \\
\text { toward school } \\
\text { activities }\end{array}$ & 4.006 & 0.414 & 3.827 & 0.484 & 3.800 & 0.322 & 3.906 & 0.492 & 4.051 & 0.220 \\
\hline $\begin{array}{l}\text { The role of } \\
\text { principals } \\
\text { toward serving } \\
\text { local } \\
\text { community }\end{array}$ & 3.658 & 0.471 & 3.440 & 0.618 & 3.317 & 0.355 & 3.545 & 0.583 & 3.692 & 0.466 \\
\hline $\begin{array}{l}\text { Domains as a } \\
\text { whole }\end{array}$ & 3.993 & 0.410 & 3.893 & 0.382 & 3.859 & 0.193 & 3.924 & 0.429 & 4.117 & 0.191 \\
\hline
\end{tabular}

Table 8. The arithmetic means and standard deviations of the respondents estimates regarding the study fields according to the "years of experience in administration" variable

\begin{tabular}{|c|c|c|c|c|c|c|}
\hline \multirow[b]{2}{*}{ Domains } & \multicolumn{2}{|c|}{ Less than 5 years } & \multicolumn{2}{|c|}{ From 5-10 years } & \multicolumn{2}{|c|}{ More than 10 years } \\
\hline & Mean & $\begin{array}{l}\text { Standard } \\
\text { deviation }\end{array}$ & Mean & $\begin{array}{l}\text { Standard } \\
\text { deviation }\end{array}$ & Mean & $\begin{array}{l}\text { Standard } \\
\text { deviation }\end{array}$ \\
\hline $\begin{array}{l}\text { The role of principals } \\
\text { toward the teachers }\end{array}$ & 4.221 & 0.391 & 4.077 & 0.517 & 4.192 & 0.437 \\
\hline $\begin{array}{l}\text { The role of principals } \\
\text { toward school activities }\end{array}$ & 3.894 & 0.477 & 3.894 & 0.499 & 3.991 & 0.301 \\
\hline $\begin{array}{l}\text { The role of principals } \\
\text { toward serving local } \\
\text { community }\end{array}$ & 3.424 & 0.506 & 3.551 & 0.589 & 3.641 & 0.516 \\
\hline Domains as a whole & 3.955 & 0.315 & 3.911 & 0.439 & 4.016 & 0.338 \\
\hline
\end{tabular}

To determine the presence of differences among the arithmetic means of the respondents' estimates regarding the role of principals in strengthening the intellectual security according to the study variables (gender, academic level, and years of experience in administration), the Multivariate Analysis of Variance (MANOVA) was used, as shown in Table 9. 
Table 9. The arithmetic means and standard deviations of the respondents estimates regarding the study fields according to the "years of experience in administration" variable

\begin{tabular}{|c|c|c|c|c|c|c|}
\hline & Field & Squares total & $\begin{array}{l}\text { Degree } \\
\text { of freedom }\end{array}$ & Mean Squares & F-value & $\begin{array}{l}\text { Significance } \\
\text { level }\end{array}$ \\
\hline \multirow[t]{4}{*}{ Gender } & $\begin{array}{l}\text { The role of } \\
\text { principals } \\
\text { toward the } \\
\text { teachers }\end{array}$ & 0.001 & 1 & 0.001 & 0.005 & 0.942 \\
\hline & $\begin{array}{l}\text { The role of } \\
\text { principals } \\
\text { toward school } \\
\text { activities }\end{array}$ & 0.849 & 1 & 0.849 & 4.099 & 0.060 \\
\hline & $\begin{array}{l}\text { The role of } \\
\text { principals } \\
\text { toward serving } \\
\text { local community }\end{array}$ & 0.958 & 1 & 0.958 & 3.183 & 0.077 \\
\hline & $\begin{array}{l}\text { Domains as a } \\
\text { whole }\end{array}$ & 0.256 & 1 & 0.256 & 1.623 & 0.205 \\
\hline \multirow[t]{4}{*}{ Academic level } & $\begin{array}{l}\text { The role of } \\
\text { principals } \\
\text { toward the } \\
\text { teachers }\end{array}$ & 0.469 & 2 & 0.156 & 0.668 & 0.574 \\
\hline & $\begin{array}{l}\text { The role of } \\
\text { principals } \\
\text { toward school } \\
\text { activities }\end{array}$ & 0.429 & 2 & 0.143 & 0.690 & 0.560 \\
\hline & $\begin{array}{l}\text { The role of } \\
\text { principals } \\
\text { toward serving } \\
\text { local community }\end{array}$ & 1.484 & 2 & 0.495 & 1.644 & 0.183 \\
\hline & $\begin{array}{l}\text { Domains as a } \\
\text { whole }\end{array}$ & 0.508 & 2 & 0.169 & 1.075 & 0.363 \\
\hline \multirow[t]{4}{*}{$\begin{array}{l}\text { Years of experience } \\
\text { in administration }\end{array}$} & $\begin{array}{l}\text { The role of } \\
\text { principals } \\
\text { toward the } \\
\text { teachers }\end{array}$ & 0.255 & 2 & 0.128 & 0.545 & 0.581 \\
\hline & $\begin{array}{l}\text { The role of } \\
\text { principals } \\
\text { toward school } \\
\text { activities }\end{array}$ & 0.161 & 2 & 0.080 & 0.388 & 0.680 \\
\hline & $\begin{array}{l}\text { The role of } \\
\text { principals } \\
\text { toward serving } \\
\text { local community }\end{array}$ & 0.700 & 2 & 0.350 & 1.163 & 0.316 \\
\hline & $\begin{array}{l}\text { Domains as a } \\
\text { whole }\end{array}$ & 0.159 & 2 & 0.080 & 0.505 & 0.605 \\
\hline Error & $\begin{array}{l}\text { The role of } \\
\text { principals } \\
\text { toward the } \\
\text { teachers }\end{array}$ & 26.481 & 112 & 0.234 & & \\
\hline
\end{tabular}




\begin{tabular}{llll}
\hline $\begin{array}{l}\text { The role of } 23.399 \\
\text { principals } \\
\text { toward school } \\
\text { activities }\end{array}$ & 112 & 0.207 \\
The role of 34.004 & 112 & 0.301 \\
principals \\
toward serving \\
local community \\
$\begin{array}{l}\text { Domains as a } 17.792 \\
\text { whole }\end{array}$
\end{tabular}

* Statistically significant at $\alpha=0.05$.

We can see from Table 9 that there are no statistically significant differences between the arithmetic means of the respondents' estimates regarding the role of principals in strengthening the intellectual security attributed to the study variables (gender, academic level, years of experience in administration).

\section{Recommendations}

In light of the results that have been reached, the researchers recommend the following:

- Activating the role of school principals by giving them greater authorities to take measures that enhance the concept of intellectual security.

- Directing school activities toward the significance of intellectual security through festivals, lectures and trips.

- Cooperating with security agencies to hold lectures and meetings concerned with strengthening intellectual security of the students and protecting them from drifting towards intolerance and extremism.

- Familiarizing parents and the local community with the concepts of intellectual security.

- Organizing advanced training courses for school principals on ways of achieving intellectual security or facing ideological extremism.

- Utilizing the leisure time of students through joining cultural, social and sports clubs.

- Future studies should be conducting with different research methods (e.g., Qualitative study) to deeply understand the subject of the current study.

\section{References}

Afifi, M. (2004). The Role of the Family in the Security of the Community. A worksheet submitted to the Seminar on Society and Security held at King Fahd Security College, Riyadh.

Al-Bura'i, W. (2002). The Role of the University in Confronting Intellectual Extremism (Unpublished PhD thesis). Faculty of Education, Alexandria University, Egypt.

Al-Haider, H. (2002). Intellectual Security vs. Intellectual Influences (A PhD thesis at the Police Academy). Egypt.

Al-Hoshan, B. (2005). The Importance of Educational Institutions in the Development of Security Awareness. In Third Seminar on Society and Security (pp. 121-139). Riyadh, King Fahd Security College.

Al-Jawarneh, A. M. B. (2011). Intellectual Security and Its Educational Applications in Arab and Islamic countries: Analytical Study. Journal of the Faculty of Education, 17(3).

Al-Luwaihiq, A. (2005). Intellectual Security, Its Nature and Regulations. Riyadh, Naif Arab University for Security Sciences.

Al-Qarni, M. (2004). Security Establishment of Educational Institutions. In Third Seminar on Society and Security (pp. 141-164). Riyadh, King Fahd Security College.

Al-Reb'i, M. (2009). The Role of the Curriculum in Strengthening the Concepts of Intellectual Security among University Students in the Kingdom of Saudi Arabia. The First National Conference of Intellectual Security, organized by King Saud University during the period 23-25/5/2009. 
Al-Suleiman, I. (2006). The Role of School Administrations in Consolidating the Intellectual Security of the Students (Unpublished master thesis). Naif Arab University for Security Sciences, Saudi Arabia.

Al-Yousuf, A. (2001). The Security Role of the School in Saudi Society. Riyadh: Naif Arab University for Security Sciences.

Faraj, A. (2004). The Task of High School Principal toward Deviant Behavior among Young People from the Perspective of Secondary Schools Principals. A worksheet submitted to the Seminar of Society and Security held at King Fahd Security College in Riyadh from 12-15/4/2004.

Johnson, D. (2005). Maintaining Intellectual Freedom in a Filtered World. Learning and Leading with Technology, 32(8), 39-41.

Karah, M. (1999). Organized Crime: Definition, Patterns and Trends. Naif Arab University for Security Sciences, Riyadh.

Khoraif, S. (2006). The Role of the Assistant School Principals in Achieving Intellectual Security among the Students (Unpublished master thesis). Naif Arab University for Security Sciences.

Mahfouz, A. (2006). Terrorism: Diagnosis and Solutions (3rd ed.). Al-Rayyan Establishment, Beirut.

Tash, A. (1993). The Epidemic of Drugs and the Role of the Media in Raising Awareness of Its Dangers. A series of lectures of the fourth cultural season, the Arab Center for Security Studies and Training, Riyadh.

Tomlinson, J. (2006). Values: The Curriculum of Moral Education. Children and Society Journal, 11(4), 242-251. http://dx.doi.org/10.1111/j.1099-0860.1997.tb00033.x

\section{Appendix A: The instrument}

In the name of Allah the Merciful, the Compassionate.

Brother/Sister school principal. Esq.

Peace, mercy and blessings of Allah upon you.

This questionnaire aims at determining the role of school principals in the Governorate of Ma'an in promoting intellectual security of the students. Kindly read the items contained in the questionnaire carefully, and answer them accurately and objectively. The information you provide will be treated confidentially and will be used only for the purposes of scientific research.

Thank you for your cooperation.

Kindly put $(\sqrt{ })$ in the appropriate box:

Gender:

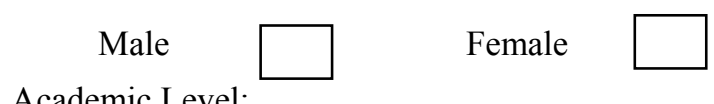

Academic Level:

Diploma $\square$ Bachelor $\square$ Master

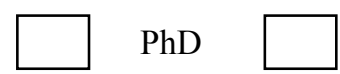

Years of Experience in Administration:

Less than 5 years $\square \quad 5-10$ years

$\square$ More than 10 years

The role of school principals in promoting the culture of intellectual security among the students.

The First Domain: "the role of principals toward teachers"

\begin{tabular}{|c|c|c|c|c|c|c|}
\hline \multirow{2}{*}{ No. } & \multirow{2}{*}{ Item } & \multicolumn{5}{|c|}{ Degree of Agreement } \\
\hline & & Very high & High & Medium & Low & Very low \\
\hline 1. & $\begin{array}{l}\text { Urging teachers to clarify the negative effects of deviant } \\
\text { thought for the students }\end{array}$ & & & & & \\
\hline 2. & $\begin{array}{l}\text { Directing teachers to link the topics of study with the } \\
\text { current situation of the community and its intellectual } \\
\text { problems }\end{array}$ & & & & & \\
\hline 3. & Encouraging teachers to enroll in courses on the art of & & & & & \\
\hline
\end{tabular}


dialogue and persuasion

4. Following-up the teachers while solving the problems of students

5. Directing teachers to use different methods of motivation for students, and avoid abuse and insult

6. Providing suitable conditions for the psychological mentor to address deviant behaviors among students

7. Holding regular meetings with teachers to study the intellectual trends of the students

8. Directing teachers to teach students different life skills such as responsibility and dialogue

9. Making teachers aware of the importance of employing the scientific method in teaching; and the development of different thinking skills of the students

10. Directing Islamic Education teachers toward instilling the right religious values and concepts

11. Working with teachers to study the causes of students dropping out of school

12. Assisting teachers in the fight against extremist ideas among students

13. Preparing teachers intellectually to fight extremist ideas among students

14. Avoiding any issues that raises bias when dealing with teachers

The Second Domain: "the role of principals toward school activities"

\begin{tabular}{|c|c|c|c|c|c|c|}
\hline \multirow{2}{*}{ No. } & \multirow{2}{*}{ Item } & \multicolumn{5}{|c|}{ Degree of Agreement } \\
\hline & & Very high & High & Medium & Low & Very low \\
\hline 1. & $\begin{array}{l}\text { Organizing exhibitions and celebrations that preserve the } \\
\text { culture of the community }\end{array}$ & & & & & \\
\hline 2. & $\begin{array}{l}\text { Hosting specialists to give lectures calling for the spreading } \\
\text { of intellectual security and the fight against delinquency }\end{array}$ & & & & & \\
\hline 3. & $\begin{array}{l}\text { Encouraging students to participate in various school } \\
\text { activities }\end{array}$ & & & & & \\
\hline 4. & $\begin{array}{l}\text { Utilizing the students' leisure time, especially in the } \\
\text { holidays, in scientific and cultural activities }\end{array}$ & & & & & \\
\hline 5. & Organizing visits to various security institutions & & & & & \\
\hline 6. & $\begin{array}{l}\text { The participation of students in the preparation of students' } \\
\text { activities }\end{array}$ & & & & & \\
\hline 7. & $\begin{array}{l}\text { Introducing elements of attraction into students' activities in } \\
\text { order to increase demand for them }\end{array}$ & & & & & \\
\hline 8. & Organizing national and religious celebrations & & & & & \\
\hline 9. & $\begin{array}{l}\text { Encouraging the students' interest in the school theater, and } \\
\text { the development of the acting skill as a means of expression }\end{array}$ & & & & & \\
\hline
\end{tabular}


The Third Domain: "the role of principals toward serving the local community"

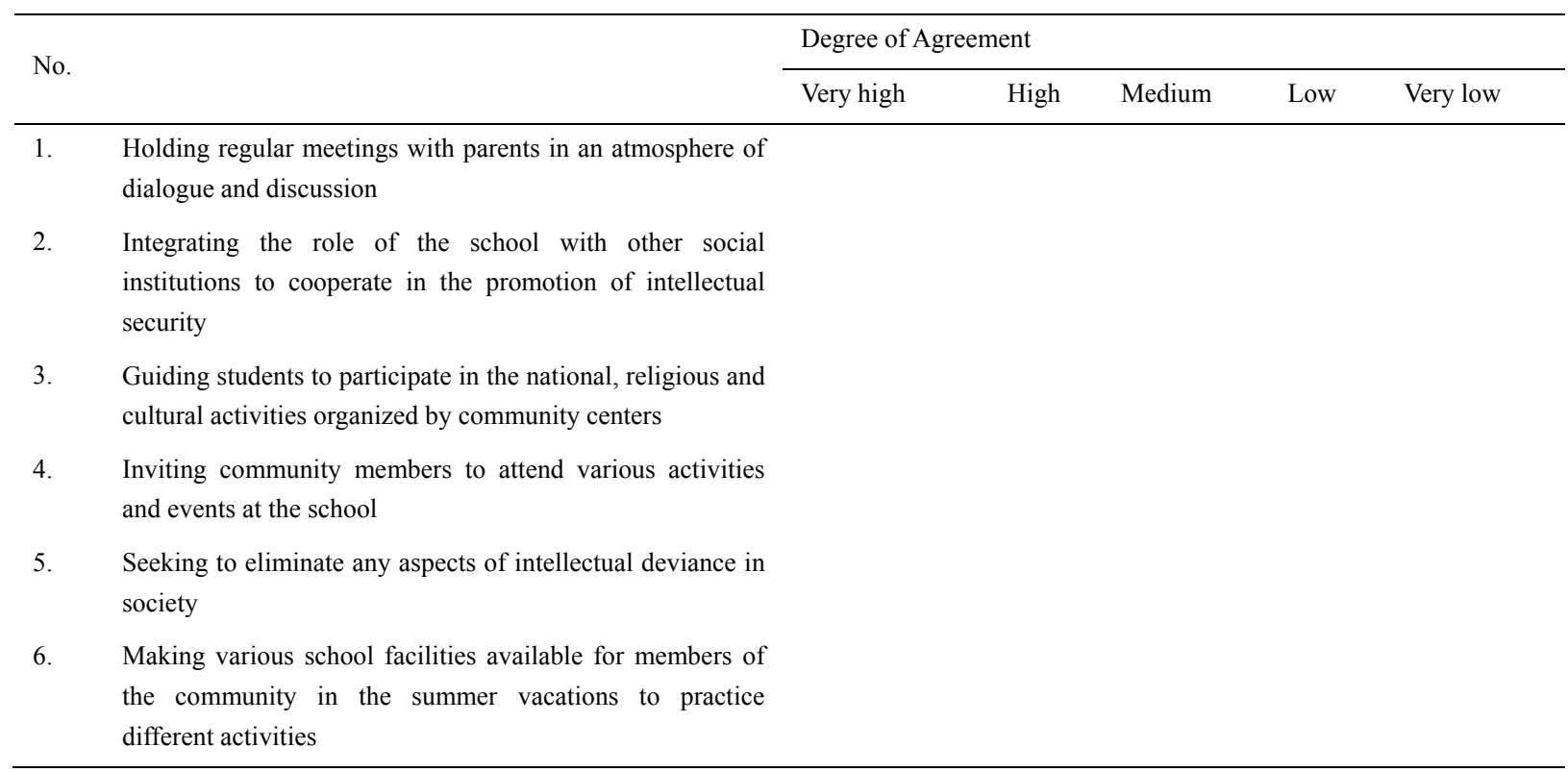

\section{Copyrights}

Copyright for this article is retained by the author(s), with first publication rights granted to the journal.

This is an open-access article distributed under the terms and conditions of the Creative Commons Attribution license (http://creativecommons.org/licenses/by/4.0/). 